OPEN ACCESS

Edited by: Robert Czajkowski, University of Gdańsk, Poland

Reviewed by: Utkarsh Manohar Bitla, National Institute of Abiotic Stress Management (ICAR), India Prem Chandra, BBA University, India

${ }^{*}$ Correspondence: Donald L. Smith donald.smith@mcgill.ca

Specialty section: This article was submitted to Microbial Symbioses, a section of the journal Frontiers in Microbiology

Received: 26 August 2021 Accepted: 26 October 2021 Published: 19 November 2021

Citation:

Naamala J and Smith DL (2021) Microbial Derived Compounds Are a Promising Approach to Mitigating Salinity Stress in Agricultural Crops. Front. Microbiol. 12:765320 doi: 10.3389/fmicb.2021.765320

\section{Microbial Derived Compounds Are a Promising Approach to Mitigating Salinity Stress in Agricultural Crops}

\author{
Judith Naamala and Donald L. Smith* \\ Smith Laboratory, Department of Plant Science, McGill University, Montreal, QC, Canada
}

The use of microbial derived compounds is a technological approach currently gaining popularity among researchers, with hopes of complementing, supplementing and addressing key issues associated with use of microbial cells for enhancing plant growth. The new technology is a promising approach to mitigating effects of salinity stress in agricultural crops, given that these compounds could be less prone to effects of salt stress, are required in small quantities and are easier to store and handle than microbial cells. Microorganism derived compounds such as thuricin17, lipochitooligosaccharides, phytohormones and volatile organic compounds have been reported to mitigate the effects of salt stress in agricultural crops such as soybean and wheat. This mini-review compiles current knowledge regarding the use of microbe derived compounds in mitigating salinity stress in crops, the mechanisms they employ as well as future prospects.

Keywords: salinity, stress, microbial derived compounds, agricultural crops, plant growth

\section{INTRODUCTION}

\section{Soil Salinity}

Soil salinity is a global problem for agricultural production, particularly in arid and semi-arid areas where crop production is significantly dependent on irrigation (Zahran, 1997, 1999; Glick, 2007; Egamberdieva and Kucharova, 2009; Egamberdieva and Lugtenberg, 2014; Shrivastava and Kumar, 2015). In the agricultural context, soil salinization refers to the accumulation of water soluble salts ions, such as $\mathrm{Na}^{+}, \mathrm{K}^{+}, \mathrm{Mg}^{2+}$ and $\mathrm{Ca}^{2+}$ and anions such as $\mathrm{Cl}^{-}, \mathrm{SO}_{4}^{2-}$, $\mathrm{HCO}_{3}^{-}, \mathrm{NO}_{3}^{-}, \mathrm{NO}_{3}^{-}$and $\mathrm{CO}_{3}^{2-}$ (Tanji, 2002; Bui, 2013; Arora et al., 2021), in the root zone, to a level detrimental to agricultural production (Rengasamy, 2006). $\mathrm{Na}^{+}, \mathrm{Cl}^{-}, \mathrm{Mg}^{2+}$ and $\mathrm{SO}_{4}^{2-}$ ions are the most dominant in saline soils, due their high solubility, and hence, ease of deposition by water, of minerals such as $\mathrm{NaCl}, \mathrm{Na}_{2} \mathrm{SO}_{4}$ and $\left[\mathrm{Na}_{2} \mathrm{Mg}\left(\mathrm{SO}_{4}\right)_{2}\right]$ (Tanji, 2002). A soil is classified as saline when the electrical conductivity of a saturated paste soil extract (ECe) is greater or equal to $4 \mathrm{dS} \mathrm{m}^{-1}$, equivalent to $40 \mathrm{mM} \mathrm{NaCl}$ (US salinity laboratory staff, 1954; Shrivastava and Kumar, 2015; Forni et al., 2017; Arora et al., 2021).

The causes of soil salinity may be natural, which results in primary salinisation, or due to human activities (anthropogenic), resulting in secondary salinization (Ghassemi et al., 1995; Tanji, 2002; Tank and Saraf, 2010; Egamberdieva and Lugtenberg, 2014; Yan et al., 2015). Geochemical weathering of minerals present in rocks is the primary natural cause (Tanji, 2002; Yan et al., 2015), although other natural factors such as: precipitation, evaporation, vegetation cover, deposition of salts from salty water bodies onto land, by wind or tsunamis, 
or the interactions among factors, cannot be ignored (Ghassemi et al., 1995; Tanji, 2002; Rengasamy, 2006).

On the other hand, irrigation is by far the major cause of human induced salinity, and is predominantly the cause of salinity in arid and semi-arid areas, where crop production is heavily dependent on irrigation (Rengasamy, 2006; Tank and Saraf, 2010; Rousk et al., 2011; Egamberdieva and Lugtenberg, 2014; Shrivastava and Kumar, 2015). Other anthropogenic factors, such as: application of fertilisers to the soil, deforestation and replacement of deep rooted perennial crops with shallow rooted annual crops have also contributed to soil salinisation, in one way or another (Tanji, 2002; Rengasamy, 2006; Tank and Saraf, 2010; Rousk et al., 2011; Shrivastava and Kumar, 2015). Deforestation and replacement of perennial crops with shallow rooted annual crops may result in a rising water table, thereby depositing dissolved salts in upper layers of the soil (Tanji, 2002; Tank and Saraf, 2010).

\section{World Spread of Soil Salinity}

Climate change and excessive use of chemicals, such as fertilizers and pesticides, are major contributors to increasing soil salinity worldwide. Approximately one third of irrigated land could be rendered unsuitable for crop production due to increasing levels of soil salinization (Dodd and Perez-Alfocea, 2012). Insuficient precipitation and high rates of evapotranspiration result in soil water loss, which explains why salinity is prevalent in arid and semi-arid regions (Zörb et al., 2019). Excessive use of chemicals, such as fertilizers and pesticides, and climate change are also responsible for increasing soil salinity around the globe. In 2020, the FAO reported that, out of the 230 million hectares of irrigated land, 45 million hectares were affected by salinity stress, and that the economic effects of salinity worldwide are estimated to be about US\$ 12 billion (FAO, 2020). Researchers reported that salinity affects approximately 1 billion ha of land worldwide, which represents about $7 \%$ of the planet's surface area (Metternicht and Zinck, 2003; Yensen, 2008). In 2002, Tanji reported that saline and sodic soils cover about $10 \%$ of the total world's arable land, although more-recent reports indicate a value as high as $50 \%$ (Yan, 2008; Xu et al., 2011). More than 100 countries worldwide have been reported to be affected by either primary or secondary salinity, or both (Tanji, 2002; Rengasamy, 2006). More than 800 million ha of land worldwide are affected by primary salinity while approximately 77 million ha are affected by secondary salinity (Ghassemi et al., 1995; Metternicht and Zinck, 2003; Yadav et al., 2011). Out of the 77 million ha affected by secondary salinity, approximately 45 million ha occur in irrigated areas (Tanji, 2002; Metternicht and Zinck, 2003). Considering that one third of the world food supply is produced on irrigated land, secondary salinization poses a very serious concern for agricultural production (Tanji, 2002). Unfortunately, due to agricultural practices and a change in climate, which has resulted in a change in rainfall patterns, evapotranspiration and landscape hydrology (Bui, 2013), soil salinization is predicted to expand at a rate of $10 \%$ annually (Shrivastava and Kumar, 2015), hence an estimated $50 \%$ of arable land is projected to be salinity affected by 2050 (Jamil et al., 2011). This high annual rate is in part attributed to the expected expansion of crop production into marginal areas, which will require irrigation (Patel et al., 2011).

\section{EFFECT OF SALINITY STRESS ON PLANTS}

Accumulation of salt ions in the soil disrupts soil properties, such as structure, water holding capacity, $\mathrm{pH}$, organic matter and nutrient content, which in turn directly or indirectly affects the capacity for plant growth in soils. Soil salinity affects plant growth and development through inducing osmotic, oxidative, and ionic stress, on the plant (Liu and Zhang, 2015; Parihar et al., 2015) As a result, plant growth at all stages, including germination, root establishment, photosynthesis, leaf area, etc. are affected, which may result in delayed maturity, as well as poor quality and quantity of yield (Parihar et al., 2015). Osmotic stress may result in reduced activity or denaturation of plant cytosolic and organelle proteins (Forni et al., 2017), decrease of cytosolic and vacuolar volumes which may negatively impact plant growth, due to reduced photosynthesis and increased production of reactive oxygen species (ROS), such as hydroxyl radicals, hydrogen peroxide, and superoxide which may be detrimental to plant cell components (Forni et al., 2017). High $\mathrm{Cl}^{-}$concentrations reduce the photosynthetic capacity and quantum yield due to chlorophyll degradation and impaired photosystem II efficiency. High $\mathrm{Na}^{+}$interferes with $\mathrm{K}^{+}$and $\mathrm{Ca}^{2+}$ nutrition, affecting stomatal regulation and decreasing photosynthesis and growth. An increase in the production of ROS, over that scavenged by plant cells, results in oxidative stress, which may result in damaging of plant cells and their components such as proteins, lipids and nucleic acids (Miller et al., 2010; Del Rio, 2015). Salinity stress also affects leaf area, chlorophyll content, plant vigour, plant height, rootlength and yield quantity and quality. Plant dry matter, nutrient, metabolite and protein contents are disrupted by salinity stress (Bistgani et al., 2019; Garcia et al., 2019). Excess salt concentrations can lead to stunting and eventual death of the plants.

\section{PGPM DERIVED COMPOUNDS FOR MITIGATION OF SALINITY STRESS}

Plant growth promoting microbes (PGPM) exude secondary metabolites such as phytohormones, exopolysaccharides, volatile organic compounds (VOCs), and other signal molecules, that have been reported to enhance plant growth under stressed and unstressed conditions (Subramanian et al., 2016; Forni et al., 2017). The compounds mitigate the effects of abiotic stress on plants, allowing the plant to grow better than it would in the presence of stress.

Plant growth promoting microbes can alleviate the effects of abiotic stresses, such as salinity, on plants. PGPM cells, have been reported to mitigate effects of salinity stress on plants for some time. However, results have been inconsistent, especially under field conditions. It should also be noted that excessive 
salt may affect growth, survival and diversity of soil microbial communities (Singleton et al., 1982), by slowing down general metabolism in cells, as well as repressing respiratory and carbonsource uptake genes (Vriezen et al., 2007; Miransari et al., 2013), which directly affects the biomass and activity of microbes (Yan and Marschner, 2012, 2013; Egamberdieva et al., 2017). Salinity causes a change in protein and metabolite structures and general morphology of the microbes, which may consequently result in loss of the microbe's ability to promote plant growth (Zahran, 1997; Soussi et al., 2001; Tewari and Arora, 2014; Nadeem et al., 2015). In rhizobia, salinity affects the entire nitrogen fixation ability of bacteria, from root colonisation and infection to affecting the nitrogenase enzyme itself (Singleton et al., 1982; Zahran, $1997,1999)$. Salinity causes a reduction in the soil water potential, which results in the flow of water out of the microbial cells into the soil, causing microbial cell drying, and lysis under severe conditions. Therefore, the idea of isolating bioactive compounds, under ideal conditions, and applying them in salt affected areas may perhaps address some of the limitations of using PGPM cells (García-García et al., 2020; Naamala and Smith, 2020, 2021; Nazari and Smith, 2020). Some microbes that produce plant growth promoting compounds can also be facultative pathogens for humans or plants, making their authorisation for use on a wider market questionable. For instance, Pseudomonas aeruginosa and Bacillus anthracis are associated with a number of human diseases (Forni et al., 2017), yet they produce high levels of compounds such as ACC deaminase. The fungus Fusarium oxysporum is a pathogen of many crop species, yet it produces VOCs that mitigated salinity stress effects in the model plant Arabidopsis thaliana, increasing chlorophyll content and leaf area (Li and Kanga, 2018). In such cases, isolating compounds in isolated and controlled conditions, from such microbes can be the most suitable way of using them to enhance plant growth, without resulting in risk to plants and humans. Use of compounds themselves may allow for control of plant exposure to such compounds, to avoid limitation associated with excess or insufficient quantities of the desired compound, something that cannot be easily done when living microbial cells are used. Additionally, PGPM derived compounds are cheaper and easier to store than PGPM cells. This would work to the advantage of farmers and agricultural product dealers that have limited storage space. A number of PGPM derived compounds have been reported to mitigate effects of salinity stress on plants; some of these are discussed below and listed and illustrated in Table $\mathbf{1}$ and Figure $\mathbf{1 .}$

\section{Phytohormones}

Plant growth promoting microbes exude phytohormones such as auxins, cytokinins, jasmonates, etc., which have been reported to enhance various aspects of plant growth, such as root length, number of root tips, shoot elongation, plant fresh and dry weight, increased chlorophyll content and photosynthetic rate, etc. (Spaepen and Vanderleyden, 2011; Belimov et al., 2015; Forni et al., 2017). This improves nutrient uptake and consequently improves plant yield quality and quantity under stressed and non-stressed conditions (Khan et al., 2019). In plants, phytohormones like abscisic acid (ABA) and jasmonic acid (JA) can be produced in response to stress, to protect plants from the effects of ROS and the resulting oxidative stress (Cappellari and Banchio, 2020). ABA and JA also play a role in many stress signaling pathways. Ethylene is also a phytohormone produced by plants in response to stress factors. However, excessive amounts of ethylene can be detrimental to plant development, resulting in reduced plant growth. The most studied phytohormones are IAA, ethylene, salicylic acid, ABA and jasmonic acid. The role of microbial phytohormones in mitigating salt stress on various plants has been reported by researchers (Egamberdieva, 2009; Bianco and Defez, 2009; Egamberdieva et al., 2013; Tewari and Arora, 2014; Egamberdieva et al., 2015; Forni et al., 2017). Strain Curtobacterium sp. SAK1 enhanced salt stress tolerance in soybean (Glycine max cv. Pungsannamu) through production of phytohormones gibberellins, IAA, and ABA (Khan et al., 2019), among other mechanisms.

\section{Enzymes}

Microbial derived enzymes, such as 1-aminocyclopropane-1carboxylate (ACC) deaminase play a significant role in mitigating the effect of salinity stress on plants. Ethylene is an essential phytohormone, required by plants at certain stages of development such as germination and ripening. However, when in excess, which is usually the case when plants encounter stress, it becomes detrimental to plant growth by promoting leaf abscission and inhibition of root elongation. The enzyme ACC deaminase lowers ethylene concentration by breaking down ACC, the precursor of ethylene, into ammonium and an energy source, alpha-keto butyrate (Glick et al., 1998; Burd et al., 2000; Tank and Saraf, 2010; Ali et al., 2014; Pérez-Montano et al., 2014; Jha and Saraf, 2015; Nadeem et al., 2015; Khan et al., 2019). Consequently, the effect of excess ethylene, that result from stress, are mitigated by the enzyme ACC deaminase. The effect of ACC deaminase in mitigating effects of salinity stress in various crop species has been reported (Mayak et al., 2004b; Saravanakumar and Samiyappan, 2007; Gamalero et al., 2010; Kasotia et al., 2012; Brígido et al., 2013; Khan et al., 2019). ACC-deaminase produced by Pseudomonas fluorescence enhanced salt tolerance in groundnut (Saravanakumar and Samiyappan, 2007) while ACC deaminase producing Curtobacterium sp. SAK1 mitigated salinity stress in soybean (Khan et al., 2019).

Other enzymes produced by PGPM, such as s catalases, superoxide dismutase and ascorbate peroxidase are antioxidants that degrade ROS such as peroxides (Lopes et al., 2021).

\section{Osmoprotectants}

Salt stress imposes osmotic and ionic stress effects on affected plants which in turn affect plant water uptake and general growth and development. Some PGPMs have been reported to produce osmoprotectants such as proline, glycerol, glutamate, glycine and trehalose (Suarez et al., 2008; Rodriguez-Salazar et al., 2009; Forni et al., 2017). Osmoprotectants are metabolites or compatible solutes with a low molecular weight, which minimise osmotic and ionic stress by controlling stomata opening and transpiration rate, maintaining plant cell turgor pressure 
and equal ion efflux across the plant cell membrane (Dodd and Perez-Alfocea, 2012; Paul and Lade, 2014; Saghafi et al., 2019), hence, enhancing plant growth under salt stress conditions. For instance, proline has been reported to mitigate effects of salinity stress in sweet pepper, cowpea, rice and tomato (Roy et al., 1993; Heuer, 2003; Hossain et al., 2011; Abdelaal et al., 2020).

\section{Volatile Organic Compounds}

Microbial VOCs have low boiling points and low molecular masses, of approximately $300 \mathrm{Da}$ and below (Veselova et al., 2019; Weisskopf et al., 2021). Microbial VOCs are emitted as secondary metabolites, at different growth stages and under different growth conditions (Fincheira et al., 2021). The major volatiles produced by microbes include: alkenes, alcohols, ketones, terpenes, benzenoids, pyrazines, acids, esters and aldehydes (Poveda, 2021). Microbial VOCs have been reported to enhance growth of plants exposed to salinity or osmotic stress (Timmusk et al., 2014; Jalali et al., 2017). For instance, Arabidopsis thaliana plants treated with VOCs from Trichoderma koningii tolerated $100 \mathrm{mM} \mathrm{NaCl}$ (Jalili et al., 2016). Pseudomonas simiae VOCs 4-nitroguaiacol and quinoline enhanced tolerance of soybean to $150 \mathrm{mM}$ salt stress (Vaishnav et al., 2016). VOCs produced by Pseudomonas simiae strain AU mitigated effects of salt stress in soybean plants by reducing $\mathrm{Na}^{+}$and increasing phosphorus and potasium concentration (Vaishnav et al., 2015). Furthermore, VOCs produced by Bacillus amyloliquefaciens GB03 increased essential oil yield in Mentha piperita L. exposed to 0, 75 and $100 \mathrm{mM} \mathrm{NaCl}$. Interestingly, the microbial VOCs are biodegradable, nontoxic and are required at lower concentrations to stimulate plant growth (Fincheira et al., 2021), which is makes VOCs desirable approaches in the PGPM technology.

\section{Exopolysaccharides}

Microbial exopolysaccharides are diverse, varying in function and structure and differ across microbial species. The concentration of EPS produced also differs across species (Bhagat et al., 2021). Their structure is complex, comprising biomolecules such polysaccharides, structural proteins, enzymes, amino sugars, nucleic acids, lipids, pyruvates, glycoproteins, etc. (Mishra and Jha, 2013). PGPM produce exopolysaccharides for reasons such as, aiding microbial attachment to plant roots and formation of biofilms (Ruppel et al., 2013; Qin et al., 2016; Liu et al., 2017b; Bhagat et al., 2021). EPS bind with cations, such as $\mathrm{Na}^{+}$, lowering their bioavailable ions and hence, plant uptake, creating osmotic balance and stabilizing the soil ionic balance, thus, mitigating osmotic and oxidative stress in plants (Kumar et al., 2020; Lopes et al., 2021). Microbial exopolysaccharides have been reported to mitigate the effect of salinity stress on different crop species such as maize, mung bean and wheat (Ashraf et al., 2004; Rojas-Tapias et al., 2012; Mahmood et al., 2016). For instance, EPS produced by Azotobacter chrococcum strains alleviated effects of salt stress in maize (Rojas-Tapias et al., 2012). Lipochitooligosaccharide is a signal molecule produced by rhizobia to communicate with its host plant. The same molecule, isolated from Bradyrhizobium japonicum has been reported to enhance plant growth under saline conditions (Gautam et al., 2016;
Subramanian et al., 2016; Nandhini and Somasundaram, 2018). Soybean seeds treated with LCO upregulated proteins essential for salt stress tolerance (Subramanian et al., 2016).

\section{N-Acyl-Homoserine Lactones}

$\mathrm{N}$-Acyl-Homoserine Lactones (AHLs) are quorum sensing signals mostly produced by gram negative bacteria, to communicate and coordinate population behavior such as siderophore production and biofilm formation (Zhao et al., 2020). They consist of a conserved homoserine lactone (HL) ring and an amide $(N)$-linked acyl side chain which is either saturated or non-saturated (Ortiz-Castro and Lopez-Bucio, 2019). A microbe can posses more than one AHL quorum sensing system. There are a number of quorum sensing molecules with both short and long carbon chains, with a carbon chain range of 4-18 carbons. Research findings show that plants can absorb AHLs through the root system and translocate them to the shoot (Sieper et al., 2014). Researchers have reported the ability of quorum sensing signals to enhance salt tolerance in plants.

TABLE 1 | Microbe derived compounds that have been reported to mitigate effects of salinity stress on crops.

\begin{tabular}{|c|c|c|c|}
\hline PGPM & $\begin{array}{l}\text { Compound } \\
\text { produced }\end{array}$ & $\begin{array}{l}\text { Crop species of } \\
\text { study }\end{array}$ & References \\
\hline $\begin{array}{l}\text { WPR-61 (unnamed } \\
\text { species) }\end{array}$ & $\begin{array}{l}\text { ACC } \\
\text { deaminase }\end{array}$ & Triticum aestivum & $\begin{array}{l}\text { Arshadullah et al., } \\
2017\end{array}$ \\
\hline $\begin{array}{l}\text { Mesorhizobium } \\
\text { cicero }\end{array}$ & $\begin{array}{l}\text { ACC } \\
\text { deaminase }\end{array}$ & Cicer arietinum L. & Brígido et al., 2013 \\
\hline $\begin{array}{l}\text { Bacillus } \\
\text { amyloliquefaciens } \\
\text { GB03 }\end{array}$ & VOCs & $\begin{array}{l}\text { Mentha piperita } L \text {, } \\
\text { Arabidopsis } \\
\text { thaliana }\end{array}$ & $\begin{array}{l}\text { Cappellari et al., 2020; } \\
\text { Zhang et al., 2008a }\end{array}$ \\
\hline $\begin{array}{l}\text { Pseudomonas } \\
\text { extremorientalis } \\
\text { TSAU20 }\end{array}$ & IAA & $\begin{array}{l}\text { Silybum } \\
\text { marianum }\end{array}$ & $\begin{array}{l}\text { Egamberdieva et al., } \\
2013\end{array}$ \\
\hline $\begin{array}{l}\text { Pseudomonas } \\
\text { aure-antiaca } \\
\text { TSAU22 }\end{array}$ & IAA & Triticum aestivum & Egamberdieva, 2009 \\
\hline $\begin{array}{l}\text { Pseudomonas } \\
\text { putida UW4 }\end{array}$ & $\begin{array}{l}\text { ACC } \\
\text { deaminase }\end{array}$ & Cucumis sativus & Gamalero et al., 2010 \\
\hline $\begin{array}{l}\text { Bacillus } \\
\text { thuringiensis }\end{array}$ & Thuricin17 & $\begin{array}{l}\text { Glycine max, Zea } \\
\text { mays and } \\
\text { Brassica napus }\end{array}$ & $\begin{array}{l}\text { Gautam et al., 2016; } \\
\text { Schwinghamer et al., } \\
\text { 2016; Subramanian } \\
\text { et al., } 2016\end{array}$ \\
\hline $\begin{array}{l}\text { Bradyrhizobium } \\
\text { japonicum }\end{array}$ & LCO & Glycine max & $\begin{array}{l}\text { Gautam et al., 2016; } \\
\text { Subramanian et al., } \\
2016\end{array}$ \\
\hline $\begin{array}{l}\text { Trichoderma } \\
\text { koningii }\end{array}$ & VOCs & $\begin{array}{l}\text { Arabidopsis } \\
\text { thaliana }\end{array}$ & Jalali et al., 2017 \\
\hline $\begin{array}{l}\text { Fusarium } \\
\text { oxysporum }\end{array}$ & VOCs & $\begin{array}{l}\text { Arabidopsis } \\
\text { thaliana }\end{array}$ & Li and Kanga, 2018 \\
\hline Verticillium dahliae & VOCs & & Li and Kanga, 2018 \\
\hline $\begin{array}{l}\text { Bacillus } \\
\text { amyloliquefaciens }\end{array}$ & VOCs & $\begin{array}{l}\text { Arabidopsis } \\
\text { thaliana }\end{array}$ & Liu et al., 2020 \\
\hline $\begin{array}{l}\text { Bradyrhizobium } \\
\text { japonicum }\end{array}$ & LCO & Zea mays & $\begin{array}{l}\text { Nandhini and } \\
\text { Somasundaram, } 2018\end{array}$ \\
\hline $\begin{array}{l}\text { Bacillus } \\
\text { amyloliquefaciens }\end{array}$ & $\begin{array}{l}\text { Abscisic acid, } \\
\text { gibberellins }\end{array}$ & Oryza sativa & $\begin{array}{l}\text { Shahzad et al., 2016, } \\
2017\end{array}$ \\
\hline $\begin{array}{l}\text { Pseudomonas } \\
\text { fluorescens }\end{array}$ & $\begin{array}{l}\text { ACC- } \\
\text { deaminase }\end{array}$ & Arachis hypogea & $\begin{array}{l}\text { Saravanakumar and } \\
\text { Samiyappan, } 2007\end{array}$ \\
\hline $\begin{array}{l}\text { Burkholderia } \\
\text { graminis, }\end{array}$ & AHLs & $\begin{array}{l}\text { Solanum } \\
\text { lycopersicum }\end{array}$ & Barriuso et al., 2008 \\
\hline
\end{tabular}


For instance, N-3-oxo-hexanoyl-homoserine lactone (3OC6HSL) enhanced rootlength, chlorophyll content and fresh weight in wheat and arabidopsis exposed to salt stress (Zhao et al., 2020). Long-chained AHL compounds produced by Burkholderia graminis, were reported to enhance both growth and salt tolerance in tomato (Barriuso et al., 2008). Nawaz et al., 2020 reported an increase in measured root variables of both salt sensitive and salt tolerant wheat cultivars inoculated with AHLs from Aeromonas spp. Therefore, AHLs are a promising approach to mitigation of salinity stress effects in agricultural crops.

\section{Bacteriocins}

Plant growth promoting microbes, especially bacteria, produce bacteriocins for various purposes such as signaling and for competition against related bacterial species (Smith et al., 2015; Subramanian and Smith, 2015; Nazari and Smith, 2020). Bacteriocins are synthesised in the ribosome of bacteria, majorly, as antimicrobials against closely related microbes (Arnison et al., 2013; Mak, 2018). There are different classes of bacteriocins, depending in part on whether they are produced by gram positive or gram negative bacteria. For instance, Chavan and Riley (2007) indicate that gram negative bacteriocins are classified as colicins, colicin-like bacteriocins, microcins, and phage tail-like. Bacteriocins from gram positive bacteria are classified as class I (sub classes Ia and Ib), class II (subclasses IIa, IIb, IIc and IId) and class III (Nazari and Smith, 2020). Although bacteriocins are mostly known for their antimicrobial properties,, recent studies show that they are able to act as microbe-to-plant signals enhancing growth and salt tolerance in a wide range of plant species. In this perspective, thuricin 17, a bacteriocin produced by the gram positive Bacillus thuringiensis NEB17 is the most studied, in relation to promotion of plant growth (Subramanian and Smith, 2015; Nazari and Smith, 2020). Subramanian et al. (2016) reported that thuricin 17 enhanced tolerance of soybean to up to $150 \mathrm{mM}$ $\mathrm{NaCl}$ stress. Arabidopsis thaliana treated with thuricin 17 tolerated up to $250 \mathrm{mM} \mathrm{NaCl}$ (Subramanian, 2014). Canola plants treated with $0.2 \mathrm{M} \mathrm{NaCl}$ and $10^{-9} \mathrm{M}$ thuricin 17 were taller than plants treated with just $0.2 \mathrm{M} \mathrm{NaCl}$ (Schwinghamer et al., 2016).

\section{MECHANISMS THROUGH WHICH MICROBE DERIVED COMPOUNDS ENHANCE PLANT TOLERANCE TO SALINITY STRESS}

There are various mechanisms through which microbe derived compounds mitigate effects of salinity stress on plants. Most of the mechanisms aim at alleviating the three major effects of salt stress, i.e., oxidative, osmotic and ionic stress. However, some mechanisms, such as increased chlorophyll content aim at increasing photosynthesis and subsequent plant growth. Upregulation of the plant's anti-oxidation system, through upregulation of anti-oxidation enzymes is one of the mechanisms exhibited by microbe derived compounds. Such enzymes include, peroxidases, catalases, superoxide dismutase, glutathione reductase and ascorbate peroxidase (Bianco and Defez, 2009;

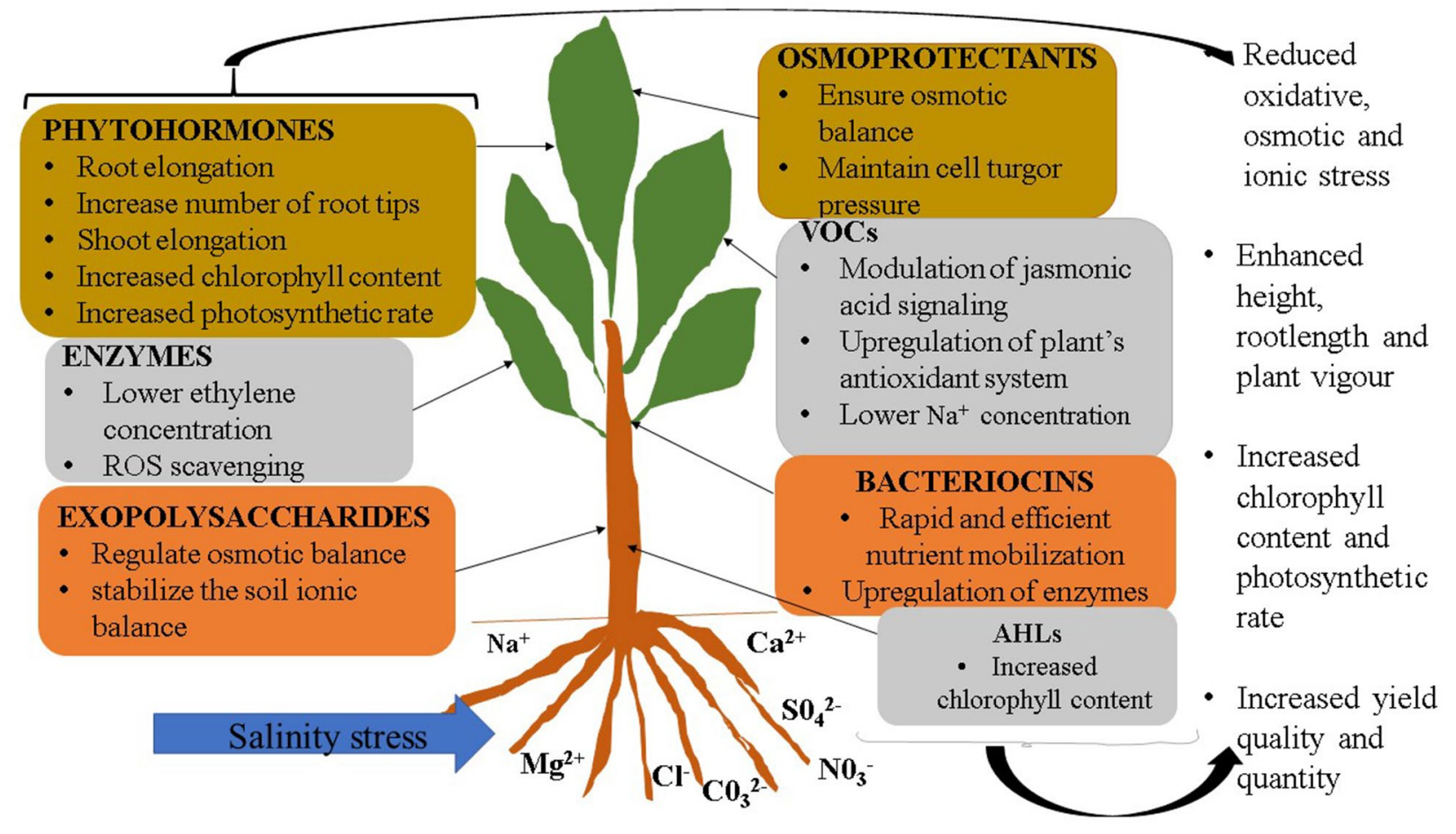

FIGURE 1 | Mechanisms employed by microbial derived compounds to mitigate salinity stress in plants. 
Forni et al., 2017). Some compounds have been reported to activate synthesis of plant genes that encode anti-oxidation enzymes (Timmusk et al., 2014), as a means of upregulating the plant's anti-oxidation system. Microbe derived VOCs increased concentration of DPPH (2,2-diphenyl-1-picrylhydrazyl) radical scavenging activity while lowering concentration of malondialdehyde (MDA) levels in pepper mint (Cappellari et al., 2020).

Improvement of ion homeostasis is another mechanisms through which compounds mitigate salinity stress in plants. This mechanisms works to eliminate osmotic and ionic stress in salt affected plants. The compounds regulate uptake of compounds and or ions such as proline, $\mathrm{K}^{+}$and $\mathrm{Na}^{+}$. For instance, some compounds such as VOCs and ACC deaminase have been reported to increase $\mathrm{K}^{+}$uptake and root to shoot $\mathrm{K}^{+}$flow while lowering $\mathrm{Na}^{+}$uptake, in plants such as Arabidopsis thaliana and soybean (Mayak et al., 2004a; Zhang et al., 2008a; Vaishnav et al., 2015). For instance, Pseudomonas simiae strain AU VOCs decreased root $\mathrm{Na}^{+}$levels and increased the accumulation of the osmoprotectant proline, in soybean (Vaishnav et al., 2015). Bacillus amyloliquefaciens FZB42 VOCs not only decreased the $\mathrm{Na}^{+}$contents of the whole plants but also induced the expression of genes such as HKT1; high-affinity $\mathrm{K}^{+}$transporter, that function to alleviate $\mathrm{Na}^{+}$toxicity (Liu et al., 2020). Upregulation of ion-homeostasis regulation genes SOS1, SOS2 and SOS3 by microbial VOCs was reported in salt stressed Arabidopsis (Zhao et al., 2020).

Upregulation of salt responsive genes such as COR15a, RD22, $A D H$, P5CS1 and ERD1 was reported (Zhao et al., 2020). Modulation of jasmonic acid signaling was also reported as a mechanism employed by Bacillus amyloliquefaciens FZB42 VOCs, in alleviating salinity stress (Liu et al., 2020). AHL 3OC6-HSL increased chlorophyll content in wheat and Arabidopsis thaliana (Zhao et al., 2020). Lowering ethylene concentration is a mechanism employed by ACC-deaminase. Production of siderophores and phosphorus solubilisation.

Soybean salt stressed seeds treated with thuricin 17 exhibited more rapid and efficient mobilization of carbon, nitrogen, and storage proteins which resulted in enhanced germination than controls (Subramanian et al., 2016a). In salt stressed Arabidopsis

\section{REFERENCES}

Abdelaal, K. A. A., El-Maghraby, L. M., Elansary, H., Hafez, Y. M., Ibrahim, E. I., El-Banna, M., et al. (2020). Treatment of sweet pepper with stress tolerance inducing compounds alleviates salinity stress oxidative damage by mediating the physio-biochemical activities and antioxidant systems. Agronomy 10:26. doi: 10.3390/agronomy10010026

Ali, S., Charles, T. C., and Glick, B. R. (2014). Amelioration of high salinity stress damage by plant growth promoting bacterial endophytes that contain ACC deaminase. Plant Physiol. Biochem. 80, 160-167. doi: 10.1016/j. plaphy.2014.04.003

Arnison, P. G., Bibb, M. J., Bierbaum, G., Bowers, A. A., Bugni, T. S., Bulaj, G., et al. (2013). Ribosomally synthesized and post-translationally modified peptide natural products: overview and recommendations for a universal nomenclature. Nat. Prod. Rep. 30, 108-160. doi: 10.1039/C2NP20085F

Arora, N. K., Egamberdieva, D., Mehnaz, S., Li, W. J., and Mishra, I. (2021). Editorial: salt tolerant Rhizobacteria: For better productivity and thaliana, treatment with thuricin17 resulted in alteration of carbon and energy metabolism pathways and upregulation of PEP carboxylase, rubisco-oxygenase, pyruvate kinase, and proteins of the light harvesting complex, energy and antioxidant pathways (Subramanian et al., 2016b).

\section{CHALLENGES AND WAY FORWARD}

Since this is a relatively new technology, there is currently limited knowledge on the technology of using microbial derived compounds, in general. Hence, there are limited compounds on the market, that have been reported to eliminate salt stress in agricultural crops. Moreover, isolation of some compounds is a complicated and time consuming process that many companies may not be willing to get involved in. There is a lot to be learned, concerning concentration, formulation, shelf life and mode of application of microbial derived compounds. Further still, majority of studies have been conducted in greenhouses and growth chambers, with limited findings under field conditions, yet, effectiveness of microbial technology is known to be inconsistent under field conditions.

There is need for more studies on microbial derived compounds and salinity stress, especially under field conditions, to address all the above mentioned challenges.

\section{AUTHOR CONTRIBUTIONS}

NJ gathered literature and wrote the mini-review. SD advised on grammar and scientific knowledge, and provided the intellectual context. All authors contributed to the article and approved the submitted version.

\section{FUNDING}

This work was funded through a grant from Consortium de recherche et innovations en bioprocédés industriels au Québec, number CRIBIQ 2017-034-C30.

remediation of saline soils. Front. Microbiol. 12:660075. doi: 10.3389/ fmicb.2021.660075

Arshadullah, M., Hyder, S. I., Mahmood, I. A., Sultan, T., and Naveed, S. (2017). Mitigation of salt stress in wheat plant (Triticum aestivum) by plant growth promoting rhizobacteria for acc deaminase. Int. J. Agric. Res. Sustain. Food Sufficiency 4, 160-164.

Ashraf, M., Hasnain, S., Berge, O., and Mahmood, T. (2004). Inoculating wheat seedlings with exopolysaccharide-producing bacteria restricts sodium uptake and stimulates plant growth under salt stress. Biol. Fertil. Soils 40, 157-162. doi: 10.1007/s00374-004-0766-y

Barriuso, J., Ramos Solano, B., Fray, R. G., Cámara, M., Hartmann, A., Javier, F., et al. (2008). Transgenic tomato plants alter quorum sensing in plant growth promoting rhizobacteria. Plant Biotechnol. J. 6, 442-452. doi: 10.1111/j.14677652.2008.00331.x

Belimov, A. A., Dodd, I. C., Safronova, V. I., Shaposhnikov, A. I., Azarova, T. S., Makarova, N. M., et al. (2015). Rhizobacteria that produce auxins and contain1-amino cyclopropane-1-carboxylic acid deaminase decrease amino acid concentrations in the rhizosphere and improve growth and yield of 
well-watered and water-limited potato (Solanum tuberosum). Ann. Appl. Biol. 167, 11-25. doi: 10.1111/aab.12203

Bhagat, N., Raghav, M., Dubey, S., and Bedi, N. (2021). Bacterial exopolysaccharides: insight into their role in plant abiotic stress tolerance. J. Microbiol. Biotechnol. 31, 1045-1059. doi: 10.4014/jmb.2105.05009

Bianco, C., and Defez, R. (2009). Medicago truncatula improves salt tolerance when nodulated by an indole-3-acetic acid overproducing Sinorhizobium meliloti strain. J. Exp. Bot. 60, 3097-3107. doi: 10.1093/jxb/erp140

Bistgani, Z. E., Hashemi, M., DaCosta, M., Craker, L., Maggi, F., and Morshedloo, M. R. (2019). Effect of salinity stress on the physiological characteristics, phenolic compounds and antioxidant activity of Thymus vulgaris $\mathrm{L}$. and thymus daenensis Celak. Ind. Crops Prod. 135, 311-320. doi: 10.1016/j.indcrop.2019.04.055

Brígido, C., Nascimento, F., Duan, J., Glick, B. R., and Oliveira, S. (2013). Expression of an exogenous 1-aminocyclopropane-1- carboxylate deaminase gene in Mesorhizobium spp. reduces the negative effects of salt stress in chickpea. FEMS Microbiol. Letters 349, 46-53. doi: 10.1111/1574-6968.12294

Bui, E. N. (2013). Soil salinity: A neglected factor in plant ecology and biogeography. J. Arid Environ. 92, 14-25. doi: 10.1016/j.jaridenv.2012.12.014

Burd, G. I., Dixon, G. D., and Glick, B. R. (2000). Plant growth-promoting bacteria that decrease heavy metal toxicity in plants. Can. J. Microbiol. 46, 237-245. doi: 10.1139/w99-143.vp

Cappellari, L. R., and Banchio, E. (2020). Microbial volatile organic compounds produced by bacillus amyloliquefaciens GB03 ameliorate the effects of salt stress in Mentha piperita principally Through Acetoin emission. J. Plant Growth Reg. 39, 764-775. doi: 10.1007/s00344-019-10020-3

Cappellari, L. d. R., Chiappero, J., Palermo, T. B., Giordano, W., and Banchio, E., (2020). Volatile organic compounds from rhizobacteria increase the biosynthesis of secondary metabolites and improve the antioxidant status in Mentha piperita L. Grown under salt stress. Agronomy 10:1094. doi: 10.3390/ agronomy10081094

Chavan, M. A., and Riley, M. A. (Eds.) (2007). "Molecular evolution of bacteriocins in Gram-negative bacteria" in Bacteriocins (Berlin, Heidelberg: Springer), $19-43$.

Del Rio, L. (2015). ROS and RNS in plant physiology: an overview. J. Exp. Bot. 66, 2827-2837. doi: 10.1093/jxb/erv099

Dodd, I. C., and Perez-Alfocea, F. (2012). Microbial amelioration of crop salinity stress. J. Exp. Bot. 63, 3415-3428. doi: 10.1093/jxb/ers033

Egamberdieva, D. (2009). Alleviation of salt stress by plant growth regulators and IAA producing bacteria in wheat. Acta Physiol. Plant. 31, 861-864. doi: 10.1007/s11738-009-0297-0

Egamberdieva, D., Davranov, K., Wirth, S., Hashem, A., and Abd Allah, E. F. (2017). Impact of soil salinity on the plant-growth - promoting and biological control abilities of root associated bacteria. Saudi J. Biol. Sci. 24, 1601-1608. doi: $10.1016 /$ j.sjbs.2017.07.004

Egamberdieva, D., Jabborova, D., and Hashem, A. (2015). Pseudomonas induces salinity tolerance in cotton (Gossypium hirsutum) and resistance to Fusarium root rot through the modulation of indole-3-acetic acid. Saudi J. Biol. Sci. 22, 773-779. doi: 10.13140/RG.2.1.5171.2164

Egamberdieva, D., Jabborova, D., and Mamadalieva, N. (2013). Salt tolerant pseudomonas extremorintalis able to stimulate growth of Silybum marianum under salt stress. Med. Arom Plant Sci. Biotechnol. 7, 7-10.

Egamberdieva, D., and Kucharova, Z. (2009). Selection for root colonizing bacteria stimulating wheat growth in saline soils. Biol. Fertil. Soil 45, 563-571. doi: 10.1007/s00374-009-0366-y

Egamberdieva, D., and Lugtenberg, (2014). "Use of plant growth-promoting rhizobacteria to alleviate salinity stress in plants," in Use of Microbes for the Alleviation of Soil Stresses. Vol. 1. ed. M. Miransari (New York: Springer Science+Business Media), 73-96.

FAO (2020). Salt-Affected Soils [Online]. Rome: FAO.

Fincheira, P., Quiroz, A., Tortella, G., Diez, M. C., and Rubilar, O. (2021). Current advances in plant-microbe communication via volatile organic compounds as an innovative strategy to improve plant growth. Microbiol. Res. 247:126726. doi: 10.1016/j.micres.2021.126726

Forni, C., Duca, D., and Glick, B. R. (2017). Mechanisms of plant response to salt and drought stress and their alteration by rhizobacteria. Plant Soil 410, 335-356. doi: 10.1007/s11104-016-3007-x

Gamalero, E., Berta, G., Massa, N., Glick, B. R., and Lingua, G. (2010). Interactions between Pseudomonas putida UW4 and Gigaspora rosea BEG9 and their consequences on the growth of cucumber under salt stress conditions. J. Appl. Microbiol. 108, 236-245. doi: 10.1111/j.1365-2672. 2009.04414.x

Garcia, C. L., Dattamudi, S., Chanda, S., and Jayachandran, K. (2019). Effect of salinity stress and microbial inoculations on Glomalin production and plant growth parameters of snap bean (Phaseolus vulgaris). Agronomy 9:545. doi: 10.3390 /agronomy 9090545

García-García, A. L., García-Machado, F. J., Borges, A. A., Morales-Sierra, S., Boto, A., and Jiménez-Arias, D. (2020). Pure organic active compounds against abiotic stress: A biostimulant overview. Front. Plant Sci. 11:575829. doi: 10.3389 /fpls.2020.575829

Gautam, K., Schwinghamer, T. D., and Smith, D. L. (2016). The response of soybean to nod factors and a bacteriocin. Plant Signaling Behav. 11:e1241934. doi: $10.1080 / 15592324.2016 .1241934$

Ghassemi, F., Jakeman, A. J., and Nix, H. A. (1995). Salinization of Land and Water Resources. Human Causes, Extent, Management, and Case Studies. Sydney: University of New South Wales Press Ltd.

Glick, B. R. (2007). Promotion of plant growth by bacterial ACC deaminase Crit. Rev. Plant Sci. 26, 227-242. doi: 10.1080/07352680701572966

Glick, B. R., Penrose, D. M., and Li, J. (1998). A model for the lowering of plant ethylene concentrations by plant growth-promoting bacteria. J. Theor. Biol. 190, 63-68. doi: 10.1006/jtbi.1997.0532

Heuer, B. (2003). Influence of exogenous application of proline and glycinebetaine on growth of salt-stressed tomato plants. Plant Sci. 165, 693-699. doi: 10.1016/ S0168-9452(03)00222-X

Hossain, M. A., Hasanuzzaman, M., and Fujita, M. (2011). Coordinate induction of antioxidant defense and glyoxalase system by exogenous proline and glycinebetaine is correlated with salt tolerance in mung bean. Front. Agric. China 5, 1-14. doi: 10.1007/s11703-010-1070-2

Jalali, F., Zafari, D., and Salari, H. (2017). Volatile organic compounds of some Trichoderma spp. increase growth and induce salt tolerance in Arabidopsis thaliana. Fungal Ecol. 29, 67-75. doi: 10.1016/j.funeco.2017.06.007

Jamil, A., Riaz, S., Ashraf, M., and Foolad, M. R. (2011). Gene expression profiling of plants under salt stress. Crit. Rev. Plant Sci. 30, 435-458.2011.605739. doi: $10.1080 / 07352689.2011 .605739$

Jha, C. K., and Saraf, M. (2015). Plant growth promoting Rhizobacteria (PGPR): a review. E3 J. Agric. Res. Dev. 5:0108-0119. doi: 10.13140/RG.2.1.5171. 2164

Kasotia, A., Jain, S., Vaishnav, A., and Kumari, S. (2012). Soybean growth promotion by pseudomonas sp. strain VS1 under salt stress. Pak. J. Biol. Sci. 15, 698-701. doi: 10.3923/pjbs.2012.698.701

Khan, M. A., Asaf, S., Khan, A. L., Ullah, I., Ali, S., Kang, S., et al. (2019). Alleviation of salt stress response in soybean plants with the endophytic bacterial isolate Curtobacterium sp. SAK1. Ann. Microbiol. 69, 797-808. doi: 10.1007/s13213-019-01470-x

Kumar, A., Singh, S., Gaurav, A. K., Srivastava, S., and Verma, J. P. (2020). Plant growth-promoting bacteria: biological tools for the mitigation of salinity stress in plants. Front. Microbiol. 11:1216. doi: 10.3389/fmicb. 2020.01216

Li, N., and Kanga, S. (2018). Do volatile compounds produced by Fusarium oxysporum and Verticillium dahliae affect stress tolerance in plants? Mycology 9, 166-175. doi: 10.1080/21501203.2018.1448009

Liu, X., Luo, Y., Li, Z., Wang, J., and Wei, G. (2017b). Role of exopolysaccharide in salt stress resistance and cell motility of Mesorhizobium alhagi CCNWXJ12-2T. Appl. Microbiol. Biotechnol. 101, 2967-2978. doi: 10.1007/s00253-017-8114-y

Liu, S., Tian, Y., Jia, M., Lu, X., Yue, L., Zhao, X., et al. (2020). Induction of salt tolerance in Arabidopsis thaliana by volatiles from bacillus amyloliquefaciens FZB42 via the jasmonic acid signaling pathway. Front. Microbiol. 11:562934. doi: $10.3389 /$ fmicb.2020.562934

Liu, X. M., and Zhang, H. (2015). The effects of bacterial volatile emissions on plant abiotic stress tolerance. Front. Plant Sci. 6:774. doi: 10.3389/fpls.2015.00774

Lopes, M. J. S., Dias-Filho, M. B., and Gurgel, E. S. C. (2021). Successful plant growth-promoting microbes: inoculation methods and abiotic factors. Front. Sustain. Food Syst. 5:606454. doi: 10.3389/fsufs.2021.606454

Mahmood, S., Daur, I., Al-Solaimani, S. G., Ahmad, S., Madkour, M. H., Yasir, M., et al. (2016). Plant growth promoting rhizobacteria and silicon synergistically enhance salinity tolerance of mung bean. Front. Plant Sci. 7:876. doi: $10.3389 /$ fpls.2016.00876

Mak, P. (2018) in Pet-to-man Travelling Staphylococci: A World in Progress. ed. V. Savini (Netherlands, Amsterdam: Elsevier), 161-171. 
Mayak, S., Tirosh, T., and Glick, B. R. (2004a). Plant growth-promoting bacteria that confer resistance to water stress in tomato and pepper. Plant Sci. 166, 525-530. doi: 10.1016/j.plantsci.2003.10.025

Mayak, S., Tirosh, T., and Glick, B. R. (2004b). Plant growth-promoting bacteria that confer resistance in tomato to salt stress. Plant Physiol. Biochem. 42, 565-572. doi: 10.1016/j.plaphy.2004.05.009

Metternicht, G. I., and Zinck, J. A. (2003). Remote sensing of soil salinity: potentials and constraints. Remote Sens. Environ. 85, 1-20. doi: 10.1016/ S0034-4257(02)00188-8

Miller, G., Suzuki, N., Ciftci-Yilmaz, S., and Mittler, R. (2010). Reactive oxygen species homeostasis and signaling during drought and salinity stresses. Plant Cell Environ. 33, 453-467. doi: 10.1111/j.1365-3040. 2009.02041.x

Miransari, M., Riahi, H., Eftekhar, F., Minaie, A., and Smith, D. L. (2013). Improving soybean (Glycine max L.) $\mathrm{N}_{2}$ fixation under stress. J. Plant. Growth. Reg. 32, 909-921. doi: 10.1007/s00344-013-9335-7

Mishra, A., and Jha, B. (2013). "Microbial exopolysaccharides," in The Prokaryotes. eds. E. Rosenberg, E. F. DeLong, S. Lory, E. Stackebrandt and F. Thompson (Berlin, Heidelberg: Springer)

Naamala, J., and Smith, D. (2020). Relevance of plant growth promoting microorganisms and their derived compounds, in the face of climate change. Agronomy 10:1179. doi: 10.3390/agronomy10081179

Naamala, J., and Smith, D. L. (2021). Microbial derived compounds, a step toward enhancing microbial inoculants technology for sustainable agriculture. Front. Microbiol. 12:634807. doi: 10.3389/fmicb.2021.634807

Nadeem, S. J., Ahmad, M., Zahir, Z. A., Javaid, A., and Ashraf, M. (2015). The role of mycorrhizae and plant growth promoting rhizobacteria (PGPR) in improving crop productivity under stressful environments. Biotechnol. $A d v$. 32, 429-448. doi: 10.1016/j.biotechadv.2013.12.005

Nandhini, D. U., and Somasundaram, E. (2018). Effects of Rhizobial nod factors (lipo chitooligosaccharide) on seedling growth of maize (Zea mays L.) under salt stress. Bangladesh J. Bot. 47, 831-837. doi: 10.18805/LR-3597

Nawaz, M. S., Arshad, A., Rajput, L., Fatima, K., Ullah, S., Ahmad, M., et al. (2020). Growth-stimulatory effect of quorum sensing signal molecule N-acylhomoserine lactone-producing multi-trait Aeromonas spp. on wheat genotypes under salt stress. Front. Microbiol. 11:553621. doi: 10.3389/fmicb.2020.553621

Nazari, M., and Smith, D. L. (2020). A PGPR-produced bacteriocin for sustainable agriculture: a review of thuricin 17 characteristics and applications. Front. Plant Sci. 11:916. doi: 10.3389/fpls.2020.00916

Ortiz-Castro, R. and López-Bucio,J. (2019). Review: Phytostimulation and root architectural responses to quorum-sensing signals and related molecules from rhizobacteria, Plant Science, 284:135-142. 10.1016/j.plantsci.2019.04.010

Parihar, P., Singh, S., Singh, R., Singh, V. P., and Prasad, S. M. (2015). Effect of salinity stress on plants and its tolerance strategies: a review. Environ. Sci. Pollut. Res. 22, 4056-4075. doi: 10.1007/s11356-014-3739-1

Patel, B. B., Patel, B. B., and Dave, R. S. (2011). Studies on infiltration of saline-alkali soils of several parts of Mehsana and Patan districts of North Gujarat. J. Appl. Technol. Environ. Sanit. 1, 87-92.

Paul, D., and Lade, H. (2014). Plant-growth-promoting rhizobacteria to improve crop growth in saline soils: a review. Agron. Sustain. Dev. 34, 737-752. doi: 10.1007/s13593-014-0233-6

Pérez-Montano, F., Alías-Villegas, C., Bellogín, R. A., del Cerro, P., Espuny, M. R., Jiménez-Guerrero, I., et al. (2014). Plant growth promotion in cereal and leguminous agricultural important plants: From microorganism capacities to crop production. Microbiol. Res. 169, 325-336. doi: 10.1016/j.micres. 2013.09.011

Poveda, J. (2021). Beneficial effects of microbial volatile organic compounds (MVOCs) in plants. Applied Soil Ecol. 168:104118. doi: 10.1016/j.apsoil.2021.104118

Qin, Y., Druzhinina, I. S., Pan, X., and Yuan, Z. (2016). Microbially mediated plant salt tolerance and microbiome-based solutions for saline agriculture. Biotechnol. Adv. 34, 1245-1259. doi: 10.1016/j.biotechadv.2016.08.005

Rengasamy, P. (2006). World salinization with emphasis on Australia. J. Exp. Bot. 57, 1017-1023. doi: 10.1093/jxb/erj108

Rodriguez-Salazar, J., Suarez, R., Caballero-Mellado, J., and Iturriaga, G. (2009). Trehalose accumulation in Azospirillum brasilense improves drought tolerance and biomass in maize plants. FEMS Microbiol. Lett. 296, 52-59. doi: 10.1111/j. 1574-6968.2009.01614.x

Rojas-Tapias, D., Moreno-Galván, A., Pardo-Díaz, S., Obando, M., Rivera, D., and Bonilla, R. (2012). Effect of inoculation with plant growth-promoting bacteria (PGPB) on amelioration of saline stress in maize (Zea mays). Appl. Soil Ecol. 61, 264-272. doi: 10.1016/j.apsoil.2012.01.006

Rousk, J., Elyaagubi, F. K., Jones, D. L., and Godbold, D. L. (2011). Bacterial salt tolerance is unrelated to soil salinity across an arid agroecosystem salinity gradient. Soil Biol. Biochem. 43, 1881-1887. doi: 10.1016/j. soilbio.2011.05.007

Roy, D., Basu, N., Bhunia, A., and Banerjee, S. K. (1993). Counteraction of exogenous L-proline with $\mathrm{NaCl}$ in salt-sensitive cultivar of rice. Biol. Plant. 35:69. doi: 10.1007/BF02921122

Ruppel, S., Franken, P., and Witzel, K. (2013). Properties of the halophyte microbiome and their implications for plant salt tolerance. Funct. Plant Biol. 40, 940-951. doi: 10.1071/FP12355

Saghafi, D., Delangiz, N., Lajayer, B. A., and Ghorbanpour, M. (2019). An overview on improvement of crop productivity in saline soils by halotolerant and halophilic PGPRs. 3 Biotech 9:261. doi: 10.1007/s13205-019-1799-0

Saravanakumar, D., and Samiyappan, R. (2007). ACC deaminase from Pseudomonas fluorescens mediated saline resistance in groundnut (Arachis hypogea) plants. J. Appl. Microbiol. 102, 1283-1292. doi: 10.1111/j.13652672.2006.03179.x

Schwinghamer, T., Souleimanov, A., Dutilleul, P., and Smith, D. (2016). The response of canola cultivars to lipo-chitooligosaccharide (nod Bj V [C18:1, MeFuc]) and thuricin 17. Plant Growth Regul. 78, 421-434. doi: 10.1007/ s10725-015-0104-4

Shahzad, R., Khan, A. L., Bilal, S., Waqas, M., Kang, S. M., and Lee, I. J. (2017). Inoculation of abscisic acid-producing endophytic bacteria enhances salinity stress tolerance in Oryza sativa. Environ. Exp. Bot. 136:68, -77. doi: 10.1016/j.envexpbot.2017.01.010

Shahzad, R., Waqas, M., Khan, A. L., Asaf, S., Khan, M. A., Kang, S. M., et al. (2016). Seed-borne endophytic Bacillus amyloliquefaciens RWL-1 produces gibberellins and regulates endogenous phytohormones of Oryza sativa. Plant Physiol. Biochem. 106, 236-243. doi: 10.1016/j.plaphy.2016.05.006

Shrivastava, P., and Kumar, R. (2015). Soil salinity: A serious environmental issue and plant growth promoting bacteria as one of the tools for its alleviation. Saudi J. Biol. Sci. 22, 123-131. doi: 10.1016/j.sjbs.2014.12.001

Sieper, T., Forczek, S., Matucha, S. M., Krämer, P., Hartmann, A., and Schröder, P. (2014). N-acyl-homoserine lactone uptake and systemic transport in barley rest upon active parts of the plant. New Phytol. 201, 545-555. doi: 10.1111/ nph.12519

Singleton, P. W., El Swaify, S. A., and Bohlool, B. B. (1982). Effect of salinity on rhizobium growth and survival. Appl. Environ. Microbiol. 44, 884-890. doi: 10.1128/aem.44.4.884-890.1982

Smith, D. L., Praslickova, D., and Ilangumaran, G. (2015). Inter-organismal signaling and management of the phytomicrobiome. Front. Plant Sci. 6:722. doi: $10.3389 /$ fpls.2015.00722

Soussi, M., Santamaria, M., Ocana, A., and Lluch, C. (2001). Effects of salinity on protein and lipopolysaccharide pattern in a salt-tolerant strain of Mesorhizobium ciceri. J. Appl. Microbiol. 90, 476-481. doi: 10.1046/j.13652672.2001.01269.x

Spaepen, S., and Vanderleyden, J. (2011). Auxin and plant-microbe interactions. Cold Spring Harb. Perspect. Biol. 3:a001438. doi: 10.1101/cshperspect.a001438

Suarez, R., Wong, A., Ramirez, M., Barraza, A., Orozco, M. C., Cevallos, M. A., et al. (2008). Improvement of drought tolerance and grain yield in common bean by overexpressing trehalose-6-phosphate synthase in rhizobia. Mol. Plant-Microbe Interact. 21, 958-966. doi: 10.1094/MPMI-21-7-0958

Subramanian, S. (2014). Mass Spectrometry Based Proteome Profiling to Understand the Effects of Lipo-Chito-Oligosaccharide and Thuricin 17 in Arabidopsis thaliana and Glycine max Under Salt Stress. Ph.D. thesis. Montreal, QC: McGill University.

Subramanian, S., Ricci, E., Souleimanov, A., and Smith, D. L. (2016a). A proteomic approach to LipoChitooligosaccharide and Thuricin 17 effects on soybean germination unstressed and salt stress. PLoS One 11:e0160660. doi: 10.1371/journal. pone.0160660

Subramanian, S., Souleimanov, A., and Smith, D. L. (2016b). Proteomic studies on the effects of lipo-chitooligosaccharide and thuricin 17 under unstressed and salt stressed conditions in Arabidopsis Thaliana. Front. Plant Sci. 7:1314. doi: $10.3389 /$ fpls.2016.01314

Subramanian, S., and Smith, D. L. (2015). Bacteriocins from the rhizosphere microbiome - from an agriculture perspective. Front. Plant Sci. 6:909. doi: $10.3389 /$ fpls.2015.00909

Tanji, K. K. (2002). "Salinity in the soil environment," in Salinity: Environment Plants - Molecules. eds. A. Läuchli and U. Lüttge (Dordrecht: Springer). 
Tank, N., and Saraf, M. (2010). Salinity-resistant plant growth promoting rhizobacteria ameliorates sodium chloride stress on tomato plants. J. Plant Interact. 5, 51-58. doi: 10.1080/17429140903125848

Tewari, S., and Arora, N. K. (2014). Multifunctional exopolysaccharides from Pseudomonas aeruginosa PF23 involved in plant growth stimulation, biocontrol and stress amelioration in sunflower under saline conditions. Curr. Microbiol. 69, 484-494. doi: 10.1007/s00284-014-0612-x

Timmusk, S., Abd El-Daim, I. A., Copolovici, L., Tanilas, T., Kännaste, A., Behers, L., et al. (2014). Drought-tolerance of wheat improved by rhizosphere bacteria from harsh environments: enhanced biomass production and reduced emissions of stress volatiles. PLoS One 9:e96086. doi: 10.1371/journal.pone.0096086

US Salinity Laboratory Staff, (1954). Diagnosis and Improvement of Saline and Alkali Soils. USDA Handbook No.60. Washington, DC: U.S. Government Printing Office.

Vaishnav, A., Kumari, S., Jain, S., Varma, A., and Choudhary, D. K. (2015). Putative bacterial volatile-mediated growth in soybean (Glycine max L. Merrill) and expression of induced proteins under salt stress. J. Appl. Microbiol. 119, 539-551. doi: 10.1111/jam.12866

Vaishnav, A., Kumari, S., Jain, S., Varma, A., Tuteja, N., and Choudhary, D. K. (2016). PGPR-mediated expression of salt tolerance gene in soybean through volatiles under sodium nitroprusside. J. Basic Microbiol. 56, 1-15. doi: 10.1002/jobm.201600188

Veselova, M. A., Plyuta, V. A., and Khmel, I. A. (2019). Volatile compounds of bacterial origin: structure, biosynthesis, and biological activity. Microbiol. 88, 261-274. doi: 10.1134/\$0026261719030160

Vriezen, J. A. C., de Bruijin, F. J., and Nusslein, K. (2007). Response of rhizobia to desiccation in relation to osmotic stress, oxygen and temperature. Appl. Environ. Microbiol. 73, 3451-3459. doi: 10.1128/AEM.02991-06

Weisskopf, L., Schulz, S., and Garbeva, P. (2021). Microbial volatile organic compounds in intra-kingdom and inter-kingdom interactions. Nat. Rev. Microbiol. 19, 391-404. doi: 10.1038/s41579-020-00508-1

Xu, G. Y., Rocha, P. S., Wang, M. L., Xu, M. L., Cui, Y. C., Li, L. Y., et al. (2011). A novel rice calmodulin-like gene, OsMSR2, enhances drought and salt tolerance and increases ABA sensitivity in Arabidopsis. Planta 234, 47-59. doi: 10.1007/s00425-011-1386-z

Yadav, S., Irfan, M., Ahmad, A., and Hayat, S. (2011). Causes of salinity and plant manifestations to salt stress: a review. J. Environ. Biol. 32, 667-685.

Yan, L. (2008). Effect of salt stress on seed germination and seedling growth of three salinity plants. Pak. J. Biol. Sci. 11, 1268-1272. doi: 10.3923/ pibs.2008.1268.1272

Yan, N., and Marschner, P. (2012). Response of microbial activity and biomass to increasing salinity depends on the final salinity, not the original salinity. Soil Biol. Biochem. 53, 50-55. doi: 10.1016/j.soilbio.2012.04.028
Yan, N., and Marschner, P. (2013). Response of soil respiration and microbial biomass to changing EC in saline soils. Soil Biol. Biochem. 65, 322-328. doi: 10.1016/j.soilbio.2013.06.008

Yan, N., Marschner, P., Cao, W., Zuo, C., and Qin, W. (2015). Influence of salinity and water content on soil microorganisms. Int. Soil Water Conserv. Res. 3, 316-323. doi: 10.1016/j.iswcr.2015.11.003

Yensen, N. P. (2008). "Halophyte uses for the twenty-first century" in Ecophysiology of High Salinity Tolerant Plants. Tasks for Vegetation Science. Vol. 40. eds. M. A. Khan and D. J. Weber (Dordrecht: Springer)

Zahran, H. H. (1997). Diversity, adaptation, and activity of the bacterial flora in saline environments. Biol. Fertil. Soils 25, 211-223. doi: 10.1007/ s003740050306

Zahran, H. H. (1999). Rhizobium-legume symbiosis and nitrogen fixation under severe conditions and in an arid climate. Microbiol. Mol. Biol. Rev. 63, 968-989. doi: 10.1128/MMBR.63.4.968-989.1999

Zhang, H., Kim, M. S., Sun, Y., Dowd, S. E., Shi, H., and Paré, P. W. (2008a). Soil bacteria confer plant salt tolerance by tissue-specific regulation of the sodium transporter HKT1. Mol. Plant-Microbe Interact. 21, 737-744. doi: 10.1094/MPMI-21-6-0737

Zhao, Q., Yang, X. Y., Li, Y., Liu, F., Cao, X. Y., Jia, Z. H., et al. (2020). N-3oxo-hexanoyl-homoserine lactone, a bacterial quorum sensing signal, enhances salt tolerance in Arabidopsis and wheat. Bot. Stud. 61:8. doi: 10.1186/ s40529-020-00283-5

Zörb, C., Geilfus, C.-M., and Dietz, K. J. (2019). Salinity and crop yield. Plant Biol. 21, 31-38. doi: 10.1111/plb.12884

Conflict of Interest: The authors declare that the research was conducted in the absence of any commercial or financial relationships that could be construed as a potential conflict of interest.

Publisher's Note: All claims expressed in this article are solely those of the authors and do not necessarily represent those of their affiliated organizations, or those of the publisher, the editors and the reviewers. Any product that may be evaluated in this article, or claim that may be made by its manufacturer, is not guaranteed or endorsed by the publisher.

Copyright $\odot 2021$ Naamala and Smith. This is an open-access article distributed under the terms of the Creative Commons Attribution License (CC BY). The use, distribution or reproduction in other forums is permitted, provided the original author(s) and the copyright owner(s) are credited and that the original publication in this journal is cited, in accordance with accepted academic practice. No use, distribution or reproduction is permitted which does not comply with these terms. 